\title{
ペーパー系摩擦材における静的強度に及ぼす構成素材の影響*
}

\author{
藤井朋之 ${ }^{* 1}$ ，東郷敬一郎 ${ }^{* 2}$, 島村佳伸 ${ }^{* 1}$ \\ 和田拓也 ${ }^{* 3}$, 伊藤洋 ${ }^{* 4}$, 片山信行 ${ }^{* 4}$
}

\section{Influence of Constituents on Quasi-Static Strength of Paper-Based Friction Materials}

\author{
Tomoyuki FUJII ${ }^{*}$, Keiichiro TOHGO, Yoshinobu SHIMAMURA, \\ Takuya WADA, Yoichi ITO and Nobuyuki KATAYAMA \\ *11 Department of Mechanical Engineering, Shizuoka University \\ 3-5-1 Johoku, Naka-ku, Hamamatsu, 432-8561, Japan
}

This paper deals with the mechanical properties of paper-based friction materials under tensile loading. In-plane tensile tests are carried out for nine kinds of friction materials in order to evaluate the mechanical properties and clarify the influence of constituents on the tensile strength and fracture toughness. The constituents of the friction materials are aramid, cellulose, carbon fiber, filler, and phenolic resin. From in-plane tensile tests the following results are obtained: (1) The stress-strain curves show the large non-linear deformation on the in-plane tensile tests with smooth specimens. The aramid and cellulose fibers are effective for improvement of the failure strain and the tensile strength, respectively. The carbon fibers are also effective to improve the Young's modulus. (2) The fracture criteria based on the net-section stress and J-integral are valid from the results of in-plane tensile tests with pre-cracked specimens. The aramid fibers are effective for improvement of the fracture toughness although the cellulose and carbon fibers have a disadvantage to improve the fracture toughness.

Key Words : Paper-Based Friction Material, In-Plane Tension, Fracture, Strength, Fracture Toughness, Regression Analysis

\section{1. 緒言}

自動車や二輪車等の輸送機器において，クラッチ機構の動力伝達部材としてペーパー系摩擦材が利用されてい る. ペーパー系摩擦材は主に有機合成繊維からなる而熱紙に，各種変性フェノール樹脂あるいは他の而熱樹脂を 含浸して作製される。ペーパー系摩擦材の微視構造は，繊維が互いに絡み合うとともに，内部に無数の微少な気 孔を有する極めて複雑な網状構造をしており，一種の複合材料と考えることができる. 近年の輸送機器の高機能 化や高出力化に伴い, 動力伝達部材である摩擦材に要求される性能はますます厳しくなっている. 摩擦材への要 求特性は，動力伝達性能を向上させるための耐摩耗性や高摩擦特性，作動中の信頼性保証するための耐熱性，耐 ジャダー性，高強度など多岐にわたり，これらをバランスよく兼ね備えた摩擦材の開発が強く要求されている. 高機能な摩擦材の開発のため, 摩擦材の機能性に及ぼす構成素材の影響の検討が必要である.

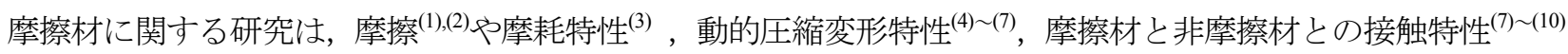
のような性能評価や高性能材の開発に関する報告が主であり, 信頼性確保を目的とした強度特性の報告は少ない. 強度評価に関する報告としては, 気孔率と機械的強度に関する研究(11) (15)やせん断負荷における疲労強度評価 ${ }^{(16)}$, 圧縮疲労特性 ${ }^{(17)}$ に関する報告がなされているが, 変形や破壊挙動, 疲労強度特性に関しては系統的な報告はされ

* 原稿受付 2011 年 7 月 8 日

${ }^{* 1}$ 正員, 静岡大学工学部（广432-8561 静岡県浜松市中区城北 3-5-1）

*2 正員, フェロー, 静岡大学工学部

*3 (株) クボタ

*4 (株) エフ・シー・シー

E-mail: ttfujii@ipc.shizuoka.ac.jp 
ておらず，未だ不明な点が多く残っている，その一方でペーパー系摩擦材の素材として利用されている，いわゆ

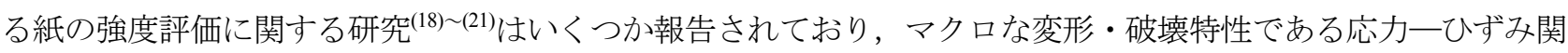
係，J 積分やき裂先端開口変位(Crack tip opening displacement, CTOD)による破壊力学的観点から強度評価を実施す るとともに，き裂進展挙動に関する報告が行われている(19),(20). しかしながら，ペーパー系摩擦材のような耐熱紙 を樹脂で結合した複雑な微視構造を有する複合材料の強度評価に, 破壊力学パラメータの適用可否は不明である.

ペーパー系摩擦材では基本的な機械的特性の評価法は未だ確立されておらず，統一的な特性評価法の確立が望 まれる. 摩擦材の引張試験を実施することで強度特性を明らかにすることにより，高機能な摩擦材の材料設計指 針を得ることができる，さらには，引張特性より実使用条件における強度特性を推定できれば，適切な材料選択 が可能となるとともに，信頼性保証も可能となる．そこで本研究では，含有する構成素材の異なる九種類のペー パー系摩擦材について，平滑材および予き裂材を対象に面内引張試験を実施し，有効な強度評価試験法および破 壊機構観察方法を確立し強度特性と破壊過程を解明するとともに，機械的特性に及ぼす構成素材の影響について 検討した.

\section{2. 実験方法と強度評価手法}

\section{$2 \cdot 1$ 供試材}

アラミド繊維, セルロース繊維，フィラー（珪藻土）及び炭素繊維を主構成素材として使用し，所定の割合で 抄造し, さらにフェノール樹脂を用い硬化させ摩擦材とした. 表 1 に各供試材の名称と各種構成素材および樹脂 の重量割合を示す．また，ペーパー系摩擦材の密度も合わせて示した．なお，供試材は摩擦材の基本的特性評価 を実施するためのモデル材料であり，含有する構成素材の名称とした．作製した摩擦材の厚さは各供試材ともに $0.5 \pm 0.02 \mathrm{~mm}$ でほぼ一定である. 水銀圧入法により測定した気孔率及び気孔径を図 1 に示す. 本研究で使用した 摩擦材は, 密度が $0.4 \mathrm{~g} / \mathrm{cm}^{3}$ 程度, 気孔率が $70 \%$ 程度の多孔質材料である. 図 2 にペーパー系摩擦紙の代表例とし

Table 1 Material compositions of paper-based friction materials. (wt $\%$ )

\begin{tabular}{c|c|c|c|c|c|c|c|c|c}
\hline & $\mathrm{A}$ & $\mathrm{C}$ & $\mathrm{AC}$ & $\mathrm{AF}$ & $\mathrm{CF}$ & $\mathrm{ACF}$ & $\mathrm{AFC}_{\mathrm{f}}$ & $\mathrm{CFC}_{\mathrm{f}}$ & $\mathrm{ACFC}_{\mathrm{f}}$ \\
\hline Aramid fiber & 70.0 & & 35.0 & 46.5 & & 23.5 & 35.0 & & 17.5 \\
\hline Cellulose fiber & & 70.0 & 35.0 & & 46.5 & 23.5 & & 35.0 & 17.5 \\
\hline Filler & & & & 23.5 & 23.5 & 23.0 & 17.5 & 17.5 & 17.5 \\
\hline Carbon fiber & & & & & & & 17.5 & 17.0 & 17.5 \\
\hline Phenolic resin & 30.0 & 30.0 & 30.0 & 30.0 & 30.0 & 30.0 & 30.0 & 30.0 & 30.0 \\
\hline Total & 100 & 100 & 100 & 100 & 100 & 100 & 100 & 100 & 100 \\
\hline Density, $\mathrm{g} / \mathrm{cm}^{3}$ & 0.38 & 0.38 & 0.39 & 0.44 & 0.42 & 0.43 & 0.41 & 0.40 & 0.43 \\
\hline
\end{tabular}

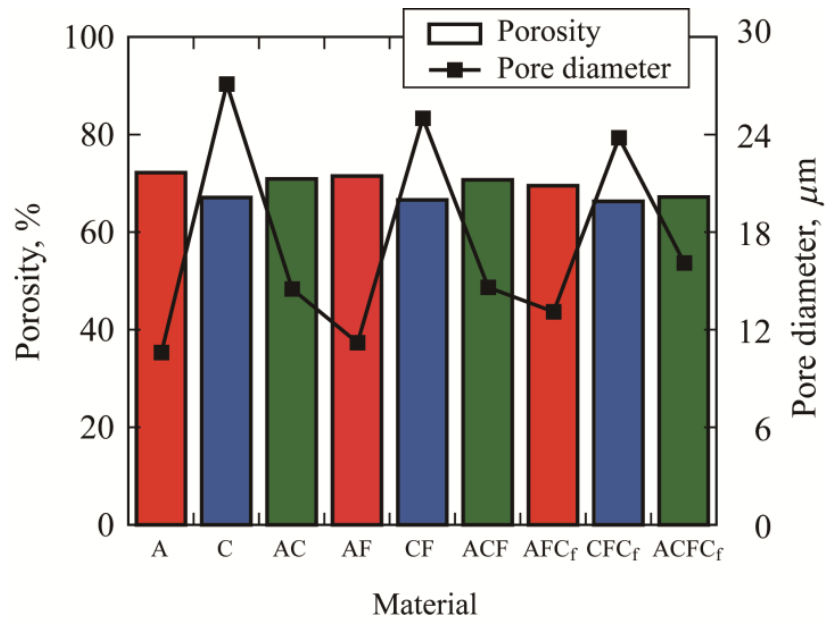

Fig. 1 Porosity and average pore diameter of paper-based friction materials. 


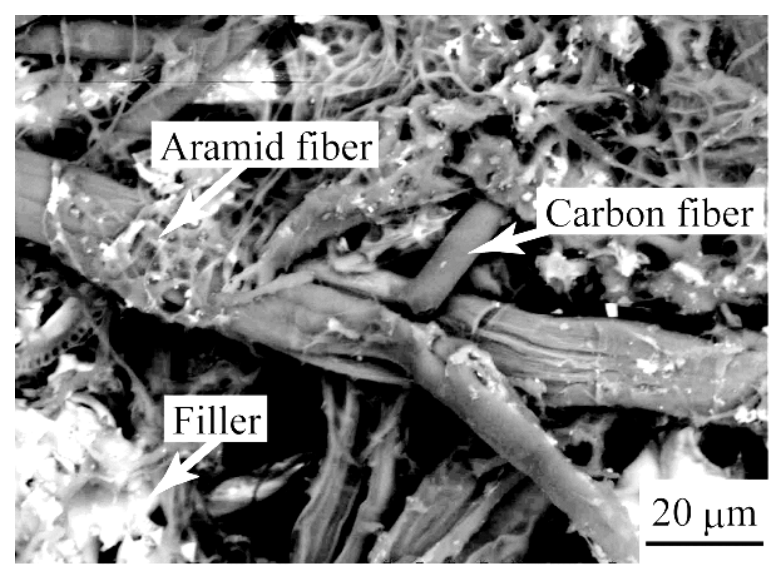

Fig. 2 Surface observation of material $\mathrm{AFC}_{\mathrm{f}}$ by scanning electron microscope.

て $\mathrm{AFC}_{\mathrm{f}}$ 材の表面写真を示す. アラミド繊維, 炭素繊維およびフィラーがランダムに配置していることがわかる. ペーパー系摩擦材は抄造により作製したため，面内方向には繊維はランダムに配置していると考えられる，

\section{$2 \cdot 2$ 試験片形状および実験方法}

面内引張試験により変形・破壞特性を導出するため, 図 3 に示すように平滑材および予き裂材の 2 種類の試験 片を作製した．平滑材は，引張方向に $100 \mathrm{~mm}$, 幅方向に $20 \mathrm{~mm}$ に切り出し作製し，試験片の両端チャック部にア ルミニウムタブを貼り付け，試験に供した．予き裂材は，引張方向に $100 \mathrm{~mm}$ ，幅方向に $30 \mathrm{~mm}$ に切り出し，試験 片中央に $4.5 \mathrm{~mm}$ および $10 \mathrm{~mm}$ の二種類の長さの予き裂を導入し作製した．なお，予き裂の導入には，鋭利な剃刀 を使用した。

引張試験は，精密万能試験機 (株式会社島津製作所，オートグラフ AGS-5)を使用し室温大気中で実施した。平 滑材では，クロスヘッドスピード $0.5 \mathrm{~mm} / \mathrm{min}$ の変位制御で行い，荷重一変位関係を記録した。予き裂材では，ク ロスヘッドスピード $0.2 \mathrm{~mm} / \mathrm{min}$ の変位制御で行い，荷重一変位関係を記録するとともに，試験中に予き裂先端を デジタルマイクロスコープにより撮影し，き裂先端開口変位(Crack tip opening displacement, CTOD)を測定した. 図 4 にCTOD の測定方法を示す．なお，図 4 は代表例として AF 材における結果を図示した. 図 4 (a)は導入した予 き裂であり，引張負荷により図 4 (b)に示寸ようにき裂先端で鈍化が生じ，次いで図 4 (c)のようにき裂先端から緎 維のほぐれ等を伴いながらき裂が進展する，上記のようなき裂挙動を示すき裂において，CTOD は予き裂先端位 置における開口変位を計測した. 平滑材の引張試験は同一条件において 5 本程度とし, 予き裂材では 3 本とした.
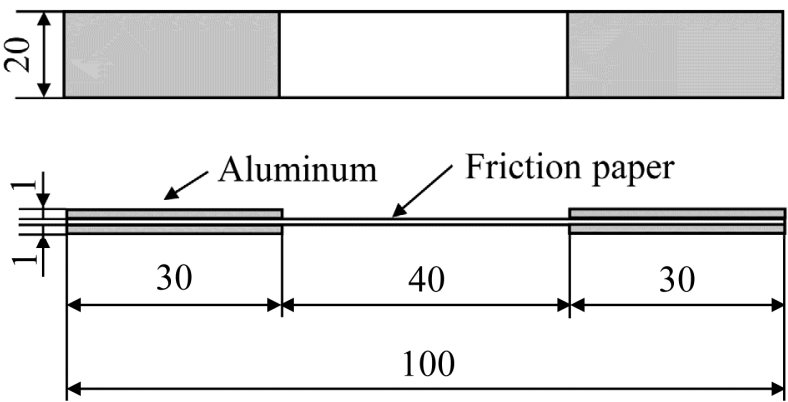

(a) Smooth specimen
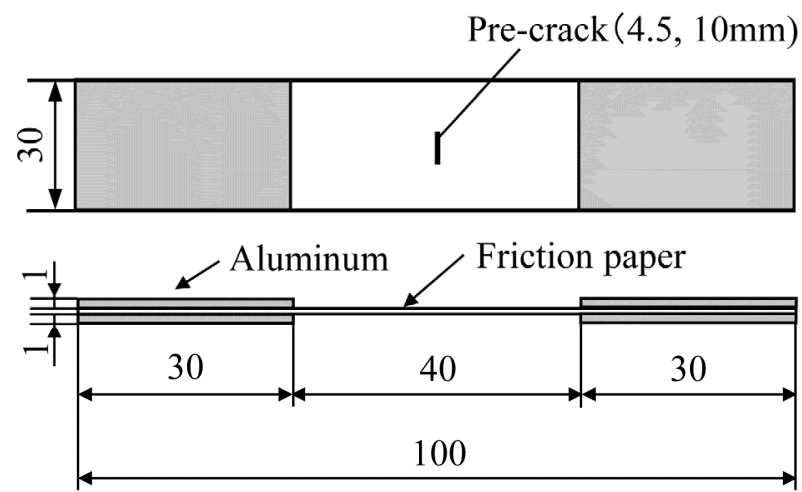

(b) Pre-cracked specimen

Fig. 3 Specimen configurations (dimensions in $\mathrm{mm}$ ). 


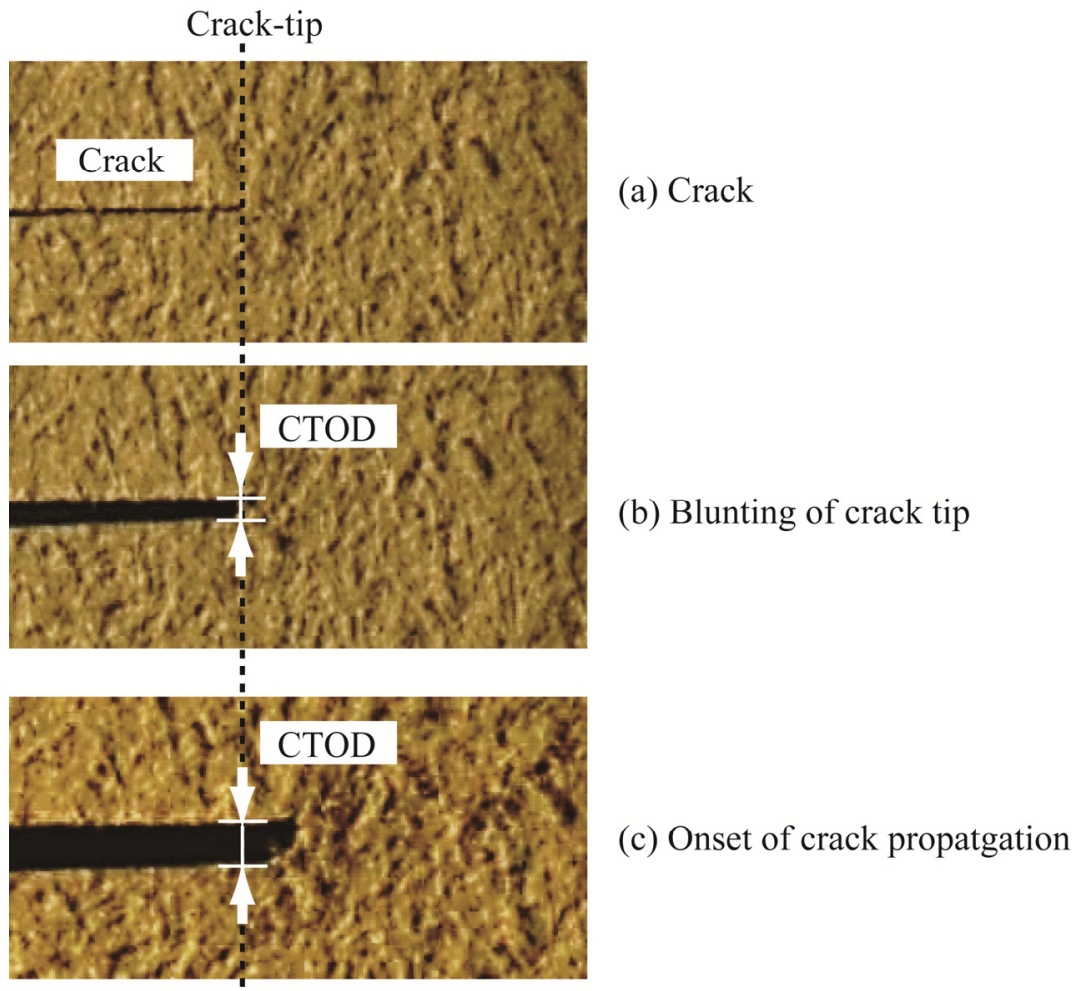

Fig. 4 Crack opening behavior and measurement of CTOD.

\section{$2 \cdot 3$ 予き裂材における強度評価}

予き裂材の引張試験において, 強度評価は正味応力および J 積分を用いた.

\section{$2 \cdot 3 \cdot 1$ 正味応力}

正味応力概念は，き裂先端の局所的応力状態によらず部材の塑性崩壊条件に着目した破壊基準である(22)．正味 応力 $\sigma_{\text {net }}$ は, 負荷荷重と最小断面積により次式で与えられる.

$$
\sigma_{\text {net }}=\frac{P}{B(W-2 a)}
$$

ここで，Pは負荷荷重， $B, W, 2 a$ はそれぞれ試験片厚さ，試験片幅，き裂長さである.

\section{$2 \cdot 3 \cdot 2 \mathrm{~J}$ 積分}

中央き裂材の面内引張負荷における $\mathrm{J}$ 積分は，荷重一変位関係より以下の簡便評価法により導出した ${ }^{(23) \sim(25)}$.

$$
J=J^{\mathrm{e}}+J^{\mathrm{p}}
$$

上式のように, $\mathrm{J}$ 積分は弾性成分 $\boldsymbol{J}^{\mathfrak{e}}$ と塑性成分 $\boldsymbol{J}^{\mathrm{p}}$ の和として表される。ここで弾性成分 $\boldsymbol{J}^{\mathfrak{P}}$ は，公称応力とき裂長 さより, 次式で与えられる.

$$
J^{\mathrm{e}}=\frac{K_{\mathrm{I}}^{2}}{E}, \quad K_{\mathrm{I}}=\sigma \sqrt{\pi a} \cdot F_{\mathrm{I}}(a), \quad F_{\mathrm{I}}(\alpha)=\sqrt{\sec \left(\frac{a}{W} \pi\right)}
$$

ここで $E$ はヤング率， $K_{\mathrm{I}}$ は応力拡大係数， $F_{\mathrm{I}}$ は形状に関する修正係数である. 塑性成分 $J^{\mathrm{p}}$ は，荷重一变位関係よ り次式で求める.

$$
J^{\mathrm{p}}=\frac{1}{b B}\left(\int_{0}^{\delta} p d \delta-\frac{1}{2} P \delta\right)
$$

ここで， $\delta$ は荷重点変位であり， $b$ はリガメント長さである. 


\section{3. 実験結果および考察}

\section{$3 \cdot 1$ 平滑材の引張特性}

図 5 に九種類の摩擦材の応力-ひずみ線図の代表例を示す.すべての摩擦材において応力ーひずみ関係は顕著な 非線形挙動となり，応力は最大に達した後に，急速に低下した，摩擦材の構成素材に着目すると，応力一ひずみ 関係は大きく異なっており，構成素材が摩擦材の変形挙動に大きく影響することがわかる，そこで，応力一ひず み関係より，構成素材が摩擦材の機械的特性に及ぼす影響を定量的に評価するため，応力一ひずみ関係よりヤン グ率，引張強さ，破断ひずみを算出した．図 6 に各種摩擦材における機械的特性を示す.

図 6(a)に九種類の摩擦材におけるヤング率を示す。なお，図中の誤差範囲は実験結果における最大值および最 小值を示す. ヤング率はセルロース繊維を含む $\mathrm{C}$ 材および $\mathrm{AC}$ 材で $750 \mathrm{MPa}$ 程度, 炭素繊維を含む $\mathrm{AFC}_{\mathrm{f}}$ 材, $\mathrm{CFC}_{\mathrm{f}}$ 材, $\mathrm{ACFC}_{\mathrm{f}}$ 材では $800 \mathrm{MPa}$ 程度であった. その一方で, アラミド䋊維を含む $\mathrm{A}$ 材, $\mathrm{ACF}$ 材ではヤング率は $600 \mathrm{MPa}$ 程度であり，セルロース繊維を含む摩擦材と比較して低いことがわかる.

図 6 (b)に九種類の摩擦材における引張強さを示す.引張強さはセルロース繊維を含む $\mathrm{C}, \mathrm{AC}$ 材で $10 \mathrm{MPa}$ 程度, アラミド繊維を含む $\mathrm{A}, \mathrm{AF}$ 材で $9 \mathrm{MPa}$ 程度であった。 その一方で，炭素繊維を含む $\mathrm{AFC}_{\mathrm{f}}$ 材， $\mathrm{CFC}_{\mathrm{f}}$ 材， $\mathrm{ACFC}_{\mathrm{f}}$ 材では 7MPa 程度であり，セルロース繊維やアラミド繊維のみを含む摩擦材よりも低いことわかる.

図 6 (c)に九種類の摩擦材における破断ひずみを示す．破断ひずみは繊維により大きく異なっており，アラミド 繊維を含む $\mathrm{A}, \mathrm{AF}$ 材の破断ひずみは 2.6\%程度であった。 セルロース繊維を含む $\mathrm{C}, \mathrm{AC}$ 材の破断ひずみは $1.9 \%$ 程度であり，炭素繊維を含む $\mathrm{AFC}_{\mathrm{f}}$ 材， $\mathrm{CFC}_{\mathrm{f}}$ 材， $\mathrm{ACFC}_{\mathrm{f}}$ 材では $1.5 \%$ 程度であった。炭素繊維を含む摩擦材は，他 の繊維を含む摩擦材に比べ，破断ひずみが小さいことがわかる.

以上の結果から，摩擦材の引張強度特性に及ぼす構成素材の効果は以下のようにまとめることができる. (1)ア ラミド繊維は，ヤング率および引張強さの向上への寄与は小さいが，破断ひずみを向上させる. (2)セルロース繊 維はヤング率，引張強さの向上に寄与し，破断ひずみに及ぼす影響は顕著ではない. (3)炭素繊維はヤング率の向 上に寄与するが，引張強さおよび破断ひずみは低下させる傾向である. (4) フィラーはヤング率を低下させる傾 向にあるものの，機械的特性に及ぼす影響は顕著ではない.

図 7 および図 8 に，それぞれ $\mathrm{A}$ 材および $\mathrm{C}$ 材の破壊形態を示寸．両材料ともに，引張方向におおよそ垂直な面 で破壊していることがわかる，また，図中の拡大図より，アラミド繊維およびセルロース繊維がほぐれることに より，破壊が進行していることがわかる，しかしながら，破壊挙動に及ぼす構成素材の影響は明確ではない．

\section{$3 \cdot 2$ 予き裂材の強度特性評価}

図 9 に，A材および C 材における予き裂材の荷重一変位関係を示寸．予き裂長さは $4.5 \mathrm{~mm}$ と $10 \mathrm{~mm}$ の二水準 とした．図中には CTOD一変位関係を合わせて示す．図中の実線は荷重一変位関係で丸印は CTOD一変位関係で ある．両材料ともに，予き裂長さによらず変位の増加とともに荷重は単調に増加し，最大荷重を超えると荷重が 急激に減少し破断した．破壊挙動は，アラミド䋊維を含む $\mathrm{A}$ 材は延性的な破壊挙動を示寸一方で，セルロース繊

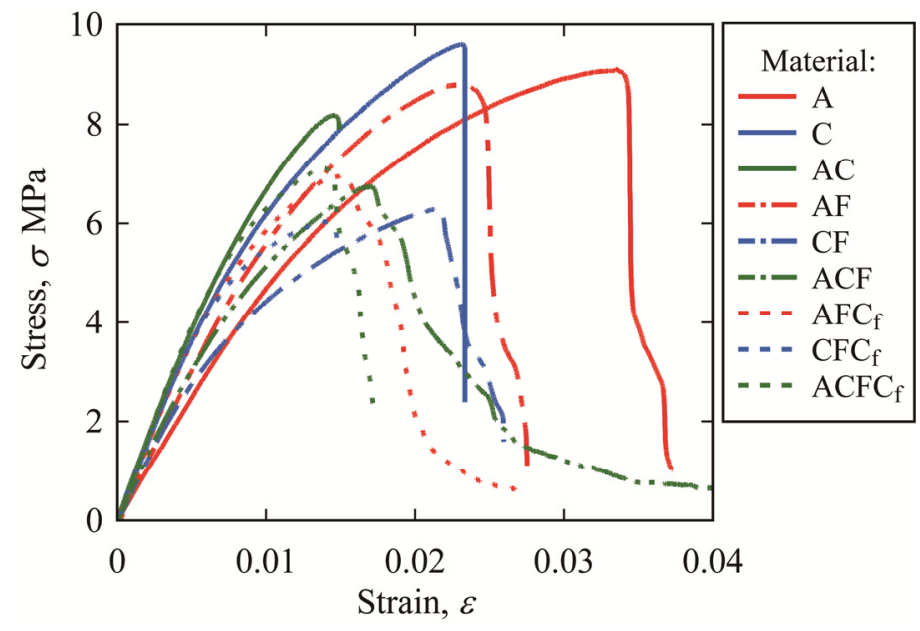

Fig. 5 Stress - strain relationship of paper-based friction materials. 


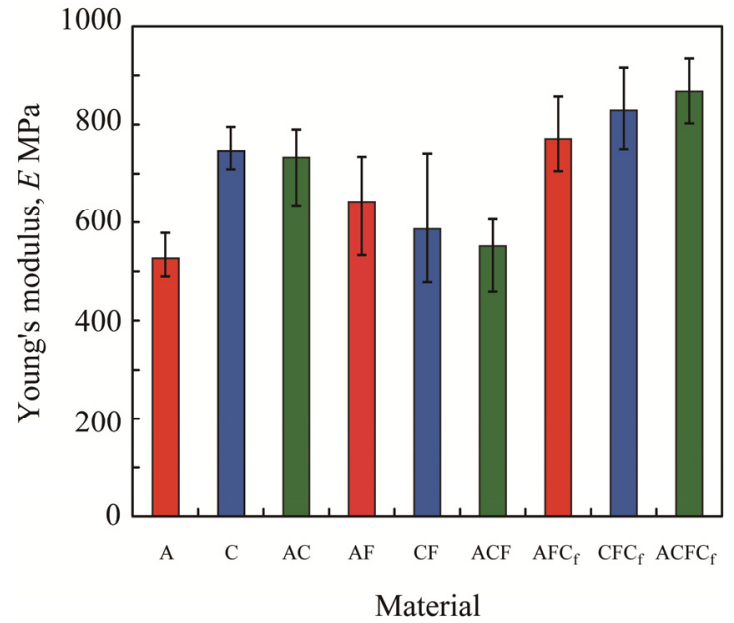

(a) Young's modulus

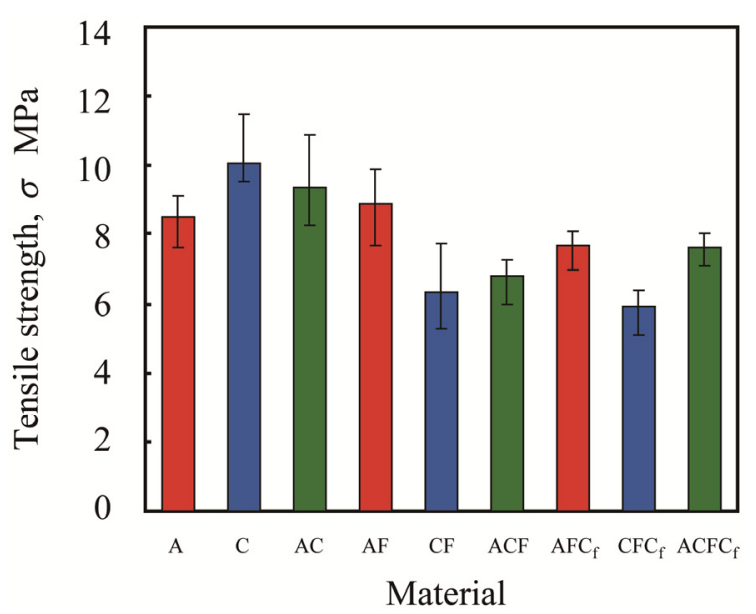

(b) Tensile strength

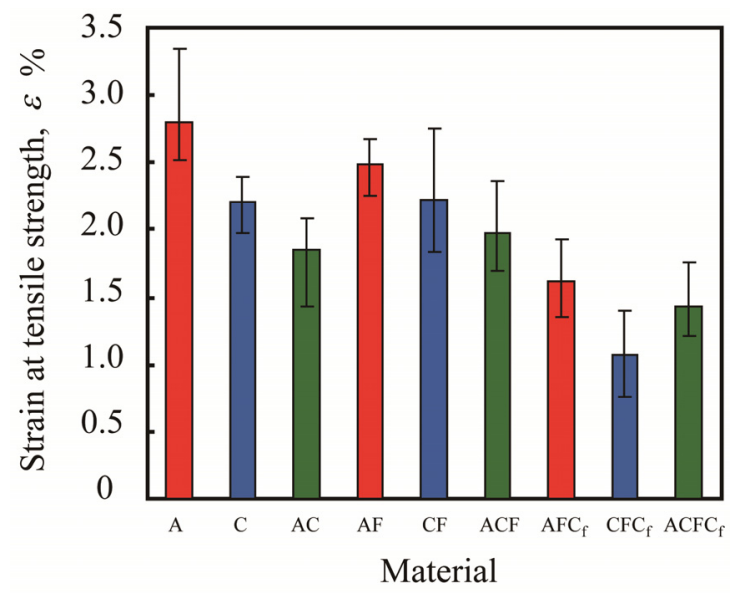

(c) Strain at tensile strength

Fig. 6 Mechanical properties of paper-based friction materials.

維を含む $\mathrm{C}$ 材は，ぜい性的な破壊挙動を示しており，破壊挙動は摩擦材を構成する構成素材により異なっている ことがわかる．破壞挙動に及ぼすアラミド繊維およびセルロース繊維の影響は，前述の平滑材における引張試験 の結果と同様であった．また，両材料ともに CTOD は変位の増加とともに増加するものの，最大荷重に達するま で増加率は低く, 最大荷重を越えると急激に増加した。つまり，最大荷重近傍で予き裂先端からき裂発生・進展 したと推察できる，そこで荷重一変位関係より，最大荷重時の正味応力および J 積分を算出した.

図 10(a)に，九種類の摩擦材における正味応力を示寸．なお図中には，前述の平滑材の引張強さを合わせて示し た．全ての摩擦材において，最大荷重時の正味応力はき裂長さに依らず引張強さにほぼ一致しており，初期き裂 を有する摩擦材の強度評価には，正味応力が有効であることがわかる．さらに，最大荷重点における正味応力に 及ぼす構成素材の影響は平滑材と同様であった。

図 10 (b)に，九種類の摩擦材の最大荷重点における $\mathrm{J}$ 積分を示寸。すべての摩擦材において，実験結果のばら つきはあるものの J 積分はき裂長さに依らずほぼ一定であることがわかる．このことより，摩擦材の巨視的き裂 進展開始条件を記述する破壞じん性は, 材料の非線形変形を考慮した $\mathrm{J}$ 積分により記述可能であることがわかる. 破壊じん性に及ぼす構成素材の影響は，セルロース繊維を含む $\mathrm{C}, \mathrm{CF}, \mathrm{CFC}_{\mathrm{f}}$ 材よりもアラミド繊維を含む $\mathrm{A}$ 材， $\mathrm{AC}$ 材および $\mathrm{ACF}$ 材のほうが高いことがわかる．またフィラーの効果は明確でなく，炭素繊維を含む $\mathrm{AFC}_{\mathrm{f}}$ 材， $\mathrm{CFC}_{\mathrm{f}}$ 材および $\mathrm{ACFC}_{\mathrm{f}}$ 材で破壊じん性が低下しており，炭素繊維は破壊じん性を低下させると考えられる.

以上の結果から，正味応力および $\mathrm{J}$ 積分は各材料のき裂材強度を整理できるが，材料による違いは $\mathrm{J}$ 積分の方 が顕著に表現できている. 


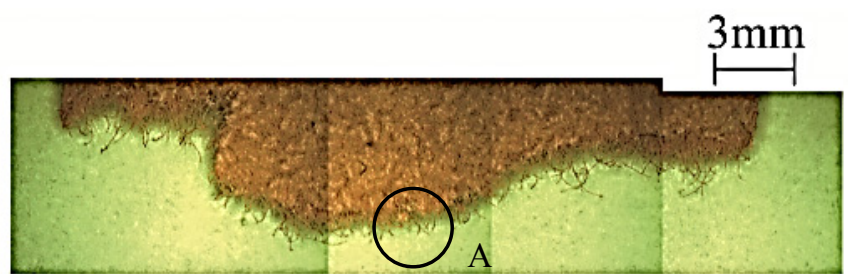

(a) Overall view

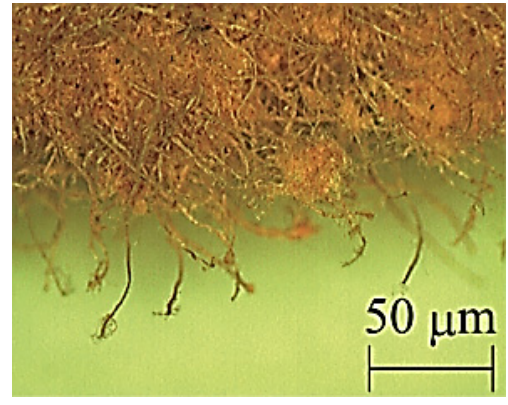

(b) Detail of part A

Fig. 7 Fracture morphology of material A.

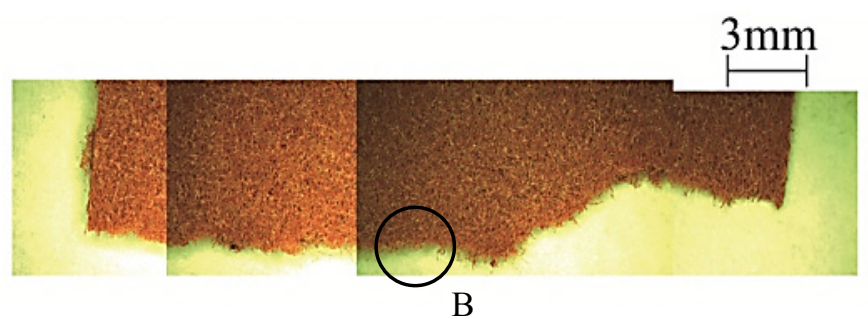

(a) Overall view

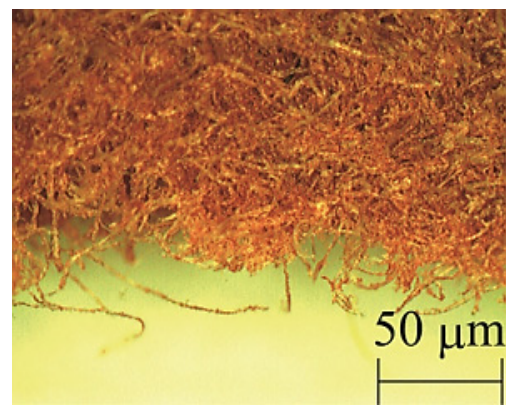

(b) Detail of part B

Fig. 8 Fracture morphology of material C.

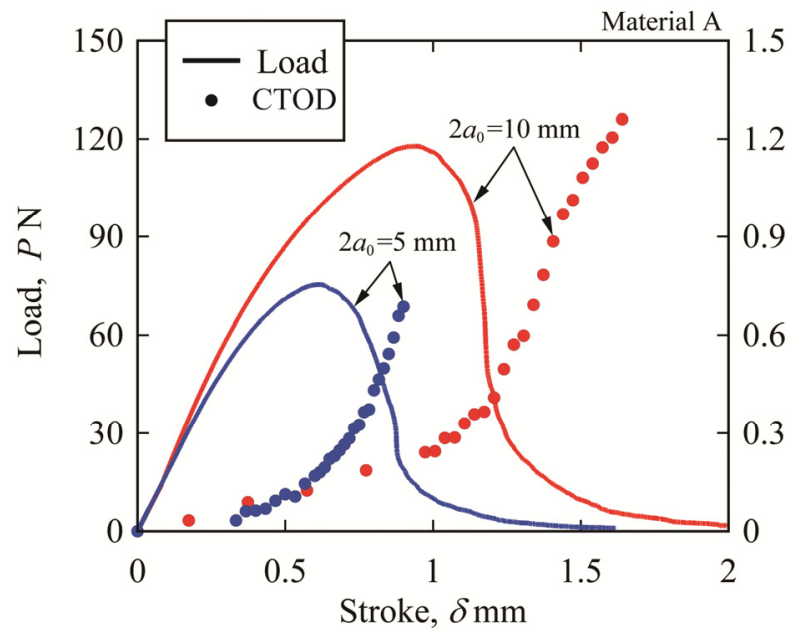

(a) Material A (Aramid)

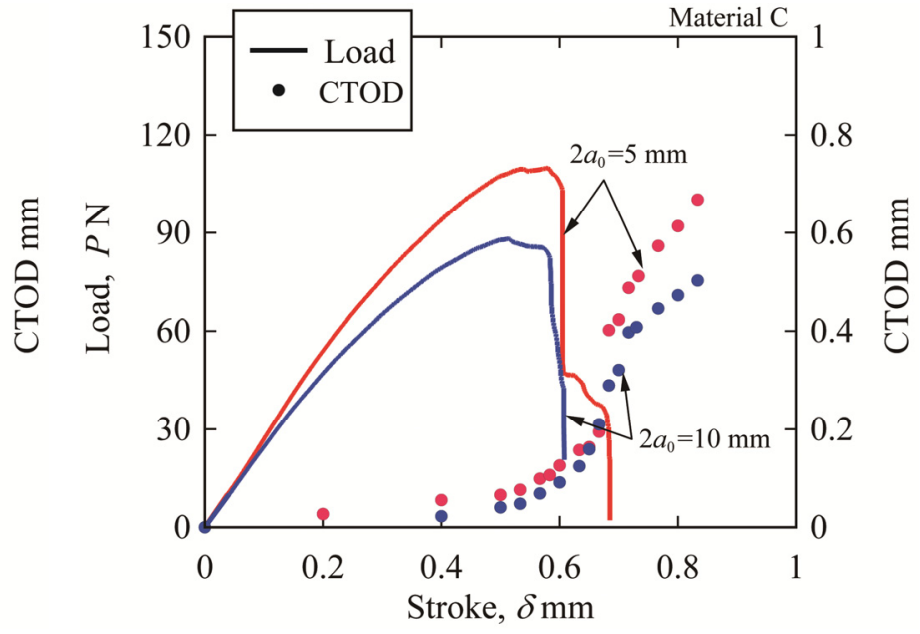

(b) Material C (Cellulose)

Fig. 9 Relationship between load, CTOD and stroke.

\section{$3 \cdot 3$ 機械的特性に及ぼす構成素材の影響の重回帰分析による評価}

上述の議論では，各種構成素材が機械的特性に及ぼす影響を定性的に評価した．本節では，重回帰分析により 引張強さ，破壊じん性に及ぼす各種構成素材の影響の定量的評価を実施し，摩擦紙の特性に影響を与える因子を 特定し，摩擦紙の機械的特性を向上寸るための指針を得ることを目的とする.

重回帰分析とは，目的変数を複数の影響因子を独立した説明変数で予測する手法であり，説明変数が目的変数 に及ぼす影響を定量的に評価することが可能となる．本研究では目的変数に機械的性質，説明変数に各種構成素 材の表 1 に示した重量割合 $(\mathrm{wt} \%)$ とし, 決定係数, 有意 $\mathrm{F}$, 推定係数, $\mathrm{t}$ 值および $\mathrm{p}$ 值により評価を行った. なお, 


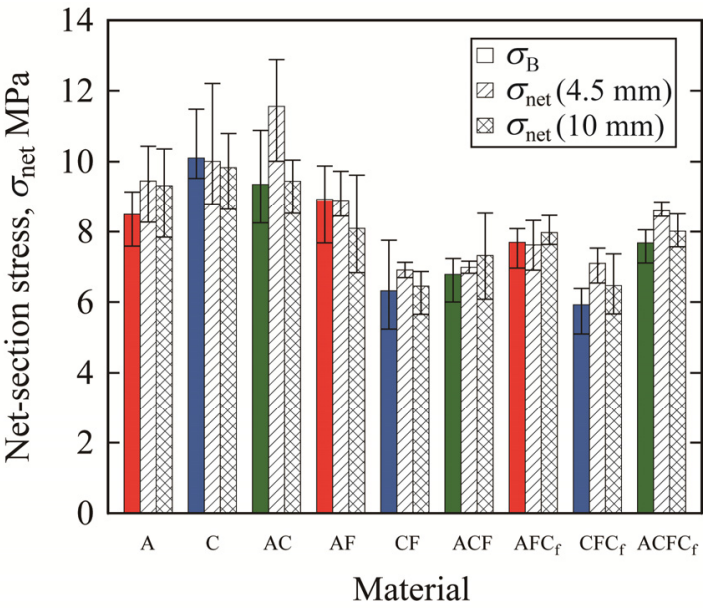

(a) Net-section stress

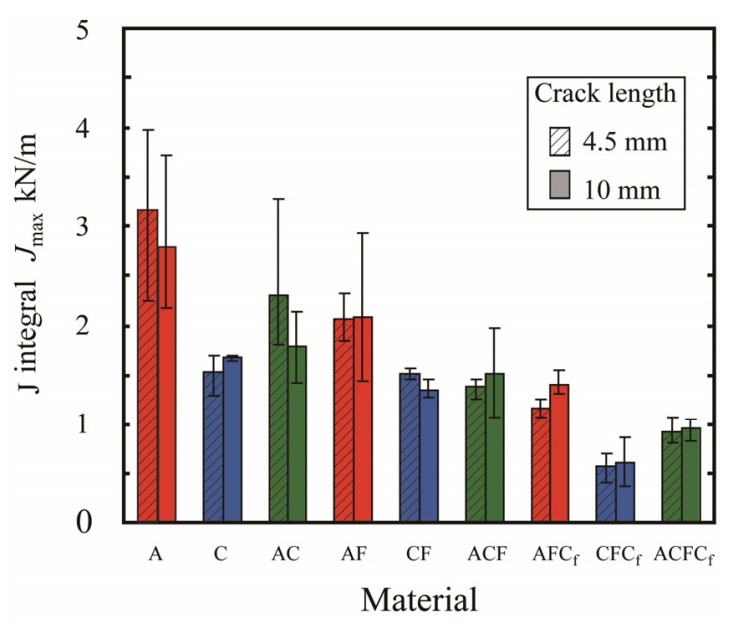

(b) J integral

Fig. 10 Fracture criterion of paper-based friction materials.

決定係数は説明変数を使った回帰式により説明できる程度の指標, 有意 $\mathrm{F}$ は説明変数が全て無効という帰無仮説 の下で偶然により標本が観測される確率の上限であり，0.05 よりも小さい場合には有意水準 $5 \%$ 見たすことを 意味する. また，推定係数は被説明変数への効果の推定值， $\mathrm{t}$ 值は目的変数を予測する上で貢献度を表す值, $\mathrm{p}$ 值 は有意確率である.

まず引張強さを目的変数とし, 説明変数にアラミド緘維とセルロース繊維の重量割合のみを用いて重回帰分析 を行った．なお，本条件では説明変数を二種の構成素材に限定した方が解析と実験結果との間により良い一致が 見られたため, 説明変数をアラミド䋊維とセルロース繊維の重量割合とした. 表 2 に解析結果の諸量を示寸. 次 式は，重回帰分析による引張強さの重回帰式を示寸．

$$
\sigma_{\mathrm{B}, \mathrm{p}}[\mathrm{MPa}]=7.08 \times 10^{-2} w_{\mathrm{A}}+6.23 \times 10^{-2} w_{\mathrm{C}}+4.55
$$

ここで， $\sigma_{\mathrm{B}, \mathrm{p}}$ は引張強さの予測值 $(\mathrm{MPa}) ， w_{\mathrm{A}}$ および $w_{\mathrm{C}}$ はそれぞれ表 1 に示したアラミド繊維およびセルロース繊 維の重量割合(wt\%)である. 重回帰式の係数および $\mathrm{t}$ 值は，アラミド繊維の方がセルロース繊維よりも大きく，ア ラミド繊維はセルロース繊維よりも，引張強度に大きな影響を及ぼすことがわかる，つまり，アラミド繊維割合 を多く寸ることにより，高強度の摩擦材を作製することができると考えられる．しかしながら，本計算結果では 決定係数が 0.39 と非常に低く, アラミド繊維およびセルロース䋊維の重量割合では引張強さの $39 \%$ を説明してい るに過ぎない. したがって，引張強さを本研究で実施した範囲の結果から十分に予測することは困難であると結 論つけけた. 図 11 に引張強さの予測值と実験值の比較を示す.すべての条件において, 予測值と実測值には大きな ばらつきがあることがわかる.

次に破壊じん性を目的変数とし, 説明変数に表 1 に示したアラミド繊維, セルロース繊維およびフィラーもし くは炭素䋊維の重量割合を用いて重回帰分析を行った．表３に解析結果の諸量を示す．次式は，重回帰分析によ る引張強さの重回帰式を示す.

$$
\begin{aligned}
& J_{\mathrm{ACF}, \mathrm{p}}[\mathrm{N} / \mathrm{m}]=33.9 w_{\mathrm{A}}+15.4 w_{\mathrm{C}}-23.2 w_{\mathrm{F}}+484.1 \\
& J_{\mathrm{ACC}_{\mathrm{f}, \mathrm{p}}}[\mathrm{N} / \mathrm{m}]=57.1 w_{\mathrm{A}}+38.6 w_{\mathrm{C}}+23.2 w_{\mathrm{C}_{\mathrm{f}}}-1141.7
\end{aligned}
$$

ここで, $J_{\mathrm{ACF}, \mathrm{p}}$ はアラミド繊維，セルロース繊維およびフィラーの重量割合より予測した $\mathrm{J}$ 積分 $(\mathrm{N} / \mathrm{m}), J_{\mathrm{ACCF}, \mathrm{p}}$

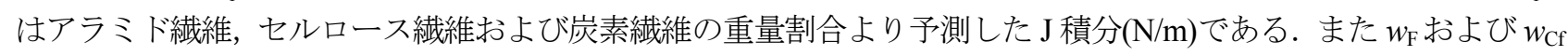
はそれぞれフィラーおよび炭素繊維の重量割合(wt\%)である. 決定係数は, 説明変数にフィラーもしくは炭素繊維 を採用した条件においても共に 0.72 であり, 構成素材の重量割合により破壊じん性の $72 \%$ を説明していることを 示している. 図 12 にアラミド繊維, セルロース繊維およびフィラーの重量割合より予測した $\mathrm{J}$ 積分と実験值の比 較を示す．予測值と実測值にはばらつきがあるものの，比較的良い相関があることがわかる．また，重回帰式の 


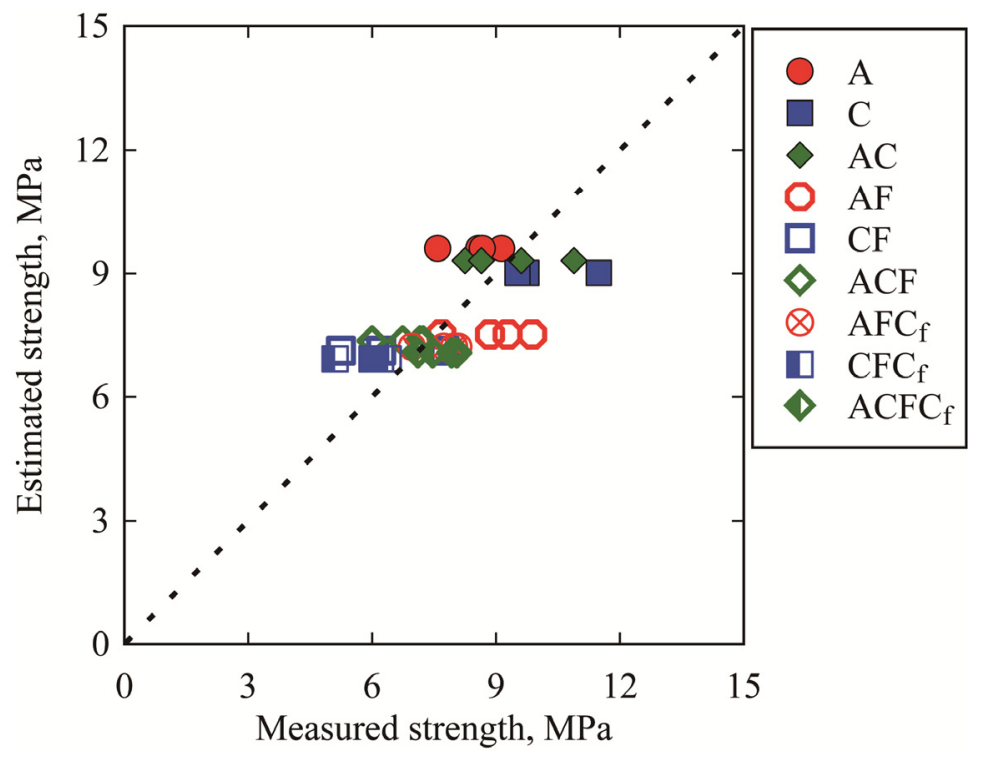

Fig. 11 Regression analysis for tensile strength.

Table 2 Details of regression analysis for tensile strength.

\begin{tabular}{l|c|c|c}
\hline Relevant independent variables & 0.39 \\
\hline \multicolumn{2}{c}{ Significance $\mathrm{F}$} & \multicolumn{2}{c}{$9.84 \times 10^{-5}$} \\
\hline \multicolumn{3}{c}{} \\
\hline Material & Coefficient & $\mathrm{t}$ & $\mathrm{p}$-value \\
\hline Aramid & $7.08 \times 10^{-2}$ & 4.92 & $2.31 \times 10^{-5}$ \\
\hline Cellulose & $6.23 \times 10^{-2}$ & 4.33 & $1.29 \times 10^{-4}$ \\
\hline
\end{tabular}

係数および $\mathrm{t}$ 值はアラミド䋊維の方がセルロース繊維に比べ高く，アラミド繊維はセルロース繊維よりも，破壊 じん性に及ぼす効果が大きいことがわかる．また，フィラーおよび炭素繊維の重回帰式の係数および $\mathrm{t}$ 值は，ア ラミド繊維と比較し小さく，破壊じん性に及ぼす影響はほとんどない，従って，高い破壊じん性の摩擦材を作製 するためには，アラミド繊維割合を多くすることが効果的であると考えられる.

以上の結果より，本研究の範囲内では引張強さに対して重回帰分析は有効でない一方で，破壊じん性に対して 重回帰分析は有効であった。さらに，アラミド繊維とセルロース繊維が摩擦紙の破壊じん值の支配因子であり， とくにアラミド繊維の重量割合を多くすることにより機械的特性に優れた摩擦材の作製が可能であることが予測 された.

なお本研究では，ペーパー系摩擦材における構成素材のみに着目し機械的特性の評価を実施した. しかしなが ら, 機械的特性は構成素材の仕様（材料，長さ，直径，表面処理等）にも影響を受けると考えられる. 従って, ペーパー系摩擦材の機械的特性に及ぼす影響の高精度評価には，構成素材およびその形状・配置も考慮する必要 がある.

\section{4. 結語}

本研究では，含有する構成素材の異なる九種類のペーパー系摩擦材について，平滑材および予き裂材を対象に 面内引張試験を実施し, 強度特性と破壊過程を解明するとともに，機械的特性に及ぼす構成素材の影響について 検討した. 以下に得られた結論を示す.

1. すべての摩擦材において応力ーひずみ関係は顕著な非線形挙動となり, 応力は最大に達した後に, 急速に低 下した，本研究で評価した構成素材の仕様（材料, 長さ，直径，表面処理等）の範囲では，ヤング率はセル ロース繊維，炭素繊維により向上し，アラミド繊維，フィラーにより低下した。引張強さはセルロース繊維 により向上し，アラミド繊維，炭素繊維により低下した．破断ひずみはアラミド繊維により向上し，セルロ ース繊維，炭素繊維により低下した。 


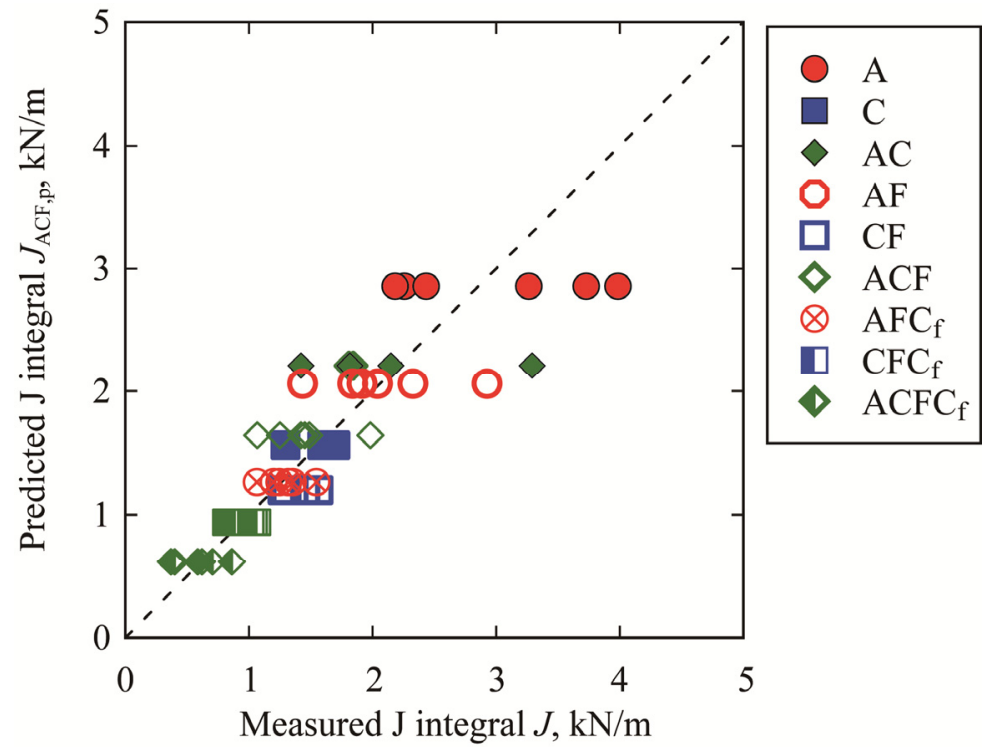

Fig. 12 Regression analysis for fracture toughness, J integral.

Table 3 Details of regression analysis for fracture toughness, J integral.

(a) Aramid, cellulose and carbon fiber

\begin{tabular}{|c|c|c|c|}
\hline \multirow{2}{*}{\multicolumn{2}{|c|}{$\begin{array}{c}\text { Relevant independent variables } \\
\text { Significance F }\end{array}$}} & \multicolumn{2}{|c|}{0.72} \\
\hline & & & $\times 10^{-14}$ \\
\hline Material & Coefficient & $\bar{t}$ & p-value \\
\hline Aramid & 33.9 & 5.54 & $1.18 \times 10^{-6}$ \\
\hline Cellulose & 15.4 & 2.54 & $1.42 \times 10^{-2}$ \\
\hline Carbon fiber & -23.2 & -2.21 & $3.20 \times 10^{-2}$ \\
\hline
\end{tabular}

(b) Aramid, cellulose and filler

\begin{tabular}{c|c|c|c}
\hline \begin{tabular}{c} 
Relevant independent variables \\
\multicolumn{3}{c}{ Significance F }
\end{tabular} & \multicolumn{2}{c}{$3.35 \times 10^{-14}$} \\
\hline \multicolumn{3}{c}{ p-value } \\
\hline Material & Coefficient & $\mathrm{t}$ & $\mathrm{p}$ \\
\hline Aramid & 57.1 & 7.94 & $2.39 \times 10^{-10}$ \\
\hline Cellulose & 38.6 & 5.32 & $2.53 \times 10^{-6}$ \\
\hline Filler & 23.2 & 2.21 & $3.20 \times 10^{-2}$ \\
\hline
\end{tabular}

2. 予き裂材の引張試験では, 最大荷重点に達した後に予き裂先端よりき裂が進展した，摩擦材のき裂強度は， 正味応力および $\mathrm{J}$ 積分で記述した破壞じん性により評価することが可能であることが分かった．本研究の範 囲では，破壊じん性はアラミド䋊維により向上し，セルロース繊維と炭素緘維により低下した.

3. 各摩擦材のき裂材強度は正味応力および $\mathrm{J}$ 積分により整理が可能であったが，材料による違いは $\mathrm{J}$ 積分の方 が顕著に表現できており，J積分に基づくき裂を有する摩擦材の評価法が有効である.

4. 重回帰分析により摩擦材の引張強さ，破壊じん性の支配因子を特定した．本研究の範囲では，アラミド䋊維 およびセルロース繊維が主に摩擦紙の機械的特性を決定する支配因子であり，フィラーおよび炭素繊維は上 記の 3 つの特性にあまり影響を与えないことが明らかとなった.

\section{文献}

(1) 井上光弘，ブレーキおよびクラッチ材料の摩擦特性，トライボロジスト，Vol. 35 (1990), pp. 690-695.

（2）江口正夫，宮崎知之，山本隆司，極低速の滑り速度一定条件下における湿式摩擦材の摩擦特性，トライボロジス ト, Vol. 44 (1999), pp. 468-471.

(3) Kimura Yoshitsugu and Otani Chikashi, Contact and wear of paper-based friction materials for oil-immersed clutches-wear model for composite materials, Tribology International, Vol. 38 (2005), pp.943-950.

(4) Natsumeda Shinichi and Miyoshi Tatsuro , Numerical Simulation of Engagement of Paper Based Wet Clutch Facing, Transaction of the ASME, Journal of Tribology, Vol. 116 (1994) , pp. 232-238.

(5) Hattori Yasuhiro and Kato Takahisa, Theory of Frictional Vibration in Wet Clutches Considering Poroelastic Properties of Paper-Based Facing, Transaction of the ASME, Journal of Tribology, Vol. 118 (1996) , pp. 520-526.

(6) L. L. TING, Engagement Behavior of Lubricated Porous Annular Disks, Wear, Vol. 34 (1975), pp. 159-172. 
（7）服部泰久, 振動荷重を受ける湿式ペーパ摩擦材の動的摩擦特性, 日本機械学会年次大会講演論文集, Vol.4 (2007), pp. 147-148.

(8) 大谷親, 木村好次, 湿式クラッチ 湿式ペーパ摩擦材の接触状態の解析, トライボロジスト, Vol. 39 (1994), pp. 1042-1046.

（9） 大谷親，岡田美津雄，木村好次，湿式ペーパ摩擦材の接触特性（第 1 報）未使用摩擦材の接触, トライボロジス 卜, Vol. 44 (1999), pp. 898-905

(10) Otani Chikasi, Observation of the Contacting Surface Conditions of the Paper-based Friction Materials using the Contact Microscope, IEICE Technical Report. EMD, Vol. 100 (2001), pp. 15-20.

(11) Eguchi Masao and Yamamoto Takashi, Shear Characteristics of a Boundary Film for a Paper-based Wet Friction Material: Friction and Real Contact Area Measurement, Tribology International, Vol. 38 (2005), pp.327-335.

(12) 北原 俊, 松本堯之, ペーパ摩擦材の多孔性と機械的強度に関する研究 (第 1 報), 日本トライボロジー学会トラ イボロジー会議予稿集，(1994）pp. 923-926.

(13) 北原 俊, 松本堯之, ペーパ摩擦材の多孔性と機械的強度に関する研究（第 2 報）, 日本トライボロジー学会トラ イボロジー会議予稿集，(1995）pp. 469-472.

(14) Matsumoto Takayuki, A Study of the Durability of a Paper-based Friction Material Influenced by Porosity, Transaction of the ASME, Journal of Tribology, Vol. 117 (1995), pp. 272-278.

(15) Kitahara Shun and Matsumoto Takayuki, The Relationship Between Porosity and Mechanical Strength in Paper-based Friction Materials, SAE TECHNICAL PAPER SERIES 960982 (1996), pp.281-287.

(16) Yih-Fang Chen and Robert C. Lam, The Shear Strength of Wet Friction Materials: Its determination and Effect on the Life of Friction Materials, SAE TECHNICAL PAPER SERIES 932923 (1993), pp.31-38.

(17) Chiba Nobutaka, Kano Makoto and INOUE Masayuki, Mechanism of Compression Fatigue of Wet Friction Materials, Transactions of Society of Automotive Engineers of Japan, Vol. 32 (2001), pp. 133-137.

(18) Tanaka Atsushi and Yamauchi Tatsuo, Size Estimation of Plastic Deformation Zone at the Crack Tip of Paper under Fracture Toughness Testing, Journal of Packaging Science and Technology, Vol. 6 (1997), pp. 268-276

(19) Tanaka Atsushi and Yamauchi Tatsuo, Crack Propagation of Paper under Fracture Toughness Testing, Journal of Packaging Science and Technology, Vol. 6 (1997), pp. 324-332.

(20) 平野大信，山内龍男，紙の破壊勒性值としての J 積分，Jc およびき裂先端開口変位 CTODc，紙パ技協誌，Vol. 54 (2000), pp.679-684.

(21) Yamauchi Tatsuo, Effect of Notches on Micro Failures During Tensile Straining of Papers, JAPAN TAPPI JOURNAL, Vol. 58 (2004), pp.1599-1601.

(22) 矢川元基, 破壊力学 理論・解析から工学的応用まで，培風館(1998), pp. 166-169.

(23) J. R. Rice, P. C. Paris and J. G. Merkle, Some Further Results of J-Integral Analysis and Estimates, ASTM STP 536(1973), pp. 231-245.

(24) N. E. Dowling, Geometry Effects and the J-Integral Approach to Elastic-Plastic Fatigue Crack Growth, ASTM STP 601(1976), pp. 19-32.

(25) 久保司郎，J 積分および修正 $\mathrm{J}$ 積分の評価とその方法，材料，Vol. 34, No. 379 (1985), pp. 359-369. 